\title{
Relation of haemostatic function, neurovascular impairment, and vibration exposure in workers with different stages of vibration induced white finger
}

\author{
M BOVENZI, ${ }^{1}$ C GIANSANTE, ${ }^{2}$ A FIORITO,${ }^{1}$ AND S CALABRESE ${ }^{2}$ \\ From the Institute of Occupational Health' and Institute of Internal Medicine, ${ }^{2}$ University of Trieste, Trieste, \\ Italy
}

ABSTRACT Haemostatic function and neurovascular symptoms were investigated in 67 workers exposed to vibration and 46 comparable referents. Of these $65.6 \%$ of vibration workers complained of neurological disturbances (stages $0_{\mathrm{T}}, 0_{\mathrm{N}}$ of Taylor's classification for vibration induced white finger (VWF) and $20.9 \%$ suffered from Raynaud's phenomenon (stages 1-2-3). The severity of the staging symptoms showed a close relation with an index of vibration dose computed on the basis of vibration measurement and individual exposure time. Indices of platelet aggregation, both in vitro and in vivo, antithrombin III, fibrinogen and fibrinopeptide $A$ levels were not different in the exposed workers compared with the referents. No relation was found between haemostatic parameters and the severity of VWF. Exposed workers responded to a cooling procedure with a more pronounced vasoconstriction in the digital vessels than the referents, as indicated by delayed recovery time of finger skin temperature after the cold test. These findings suggest that both in the early stages $\left(0_{\mathrm{T}}, 0_{\mathrm{N}}\right)$ and in more severe stages of VWF (stages 1-2) cold induced hyperreactivity in the digital vessels and Raynaud's syndrome are vascular disorders of functional origin occurring without any prethrombotic alterations.

Abnormal haemostatic function has been reported in primary Raynaud's disease and in secondary Raynaud's phenomenon.' Zahavi et al found that platelet aggregation induced by adenosinediphosphate (ADP) and beta-thromboglobulin were higher in patients suffering from Raynaud's phenomenon than in referents. ${ }^{2}$ Lower threshold concentration for ADP induced platelet aggregation was reported by Blunt $e t$ al in female patients with Raynaud's syndrome compared with referents. ${ }^{3}$ Some authors have suggested that platelet abnormalities might be involved in the pathogenesis of the digital vasospasm, ${ }^{4}$ but whether platelet disorders are the cause or the effect in the peripheral vasospastic syndrome is still unknown.

Raynaud's phenomenon is the most important component of vibration syndrome, which includes the complex of osteoarticular, neurological, and vascular lesions occurring in the hands of workers exposed to hand-arm vibration. Among the

Received 30 August 1984 Accepted 15 October 1984 pathogenic theories on the onset and perpetuation of Raynaud's phenomenon of occupational origin, one emphasises the role of endothelial injury secondary to enhanced arterial wall shear stress induced by the excessive mechanical energy entering the fingers of subjects who use handheld vibratory tools. $^{5}$ As a consequence, haemostatic disorders might be observed in vibration exposed workers affected with peripheral vasospastic symptoms. Few reports exist on this topic. Both generic hypocoagulability, ${ }^{6}$ and a tendency to hypercoagulability as indicated by increased fibrinogen concentration ${ }^{7}$ and a shortening of the heparin thrombin clotting time ${ }^{3}$ have been reported in workers with Raynaud's phenomenon. In patients exposed to hand-arm vibration for a long time in vitro platelet aggregation indices were found to be higher than in normal subjects. ${ }^{8}$ In a previous report we failed to observe a significant difference in platelet function tests and clotting parameters between 22 vibration exposed workers and 20 comparable referents. ${ }^{9}$ Among the exposed workers, however, only one man suffered from vibration induced 
white finger (VWF), the others having no symptoms or neurological disturbances.

The purpose of the present study was to investigate the relation among haemostatic function, neurovascular symptoms, and vibration exposure in a larger sample of exposed workers at different stages of vibration induced white finger.

\section{Materials and methods}

\section{SUBJECTS}

Sixty seven operators using pneumatic chipping and grinding tools at a large grey iron foundry were examined. Health status and occupational histories were collected by a standardised questionnaire administered by trained nurses. Neurological and vascular symptoms in the fingers, such as tingling, numbness, and blanching, were classified according to the stage system for VWF described by Taylor et al. ${ }^{10}$ The workers were also questioned as to their use of tobacco and alcohol. A general clinical examination was carried out by two physicians who carefully examined the target organs affected by exposure to vibration and confirmed the stage assessment for VWF. Exposure time to segmentál vibration was estimated both as hand tool usage years and as total working hours" ${ }^{1}$ because of the difference in daily exposure time (h) among the vibration workers.

Forty six healthy men working at the foundry and not exposed to vibration formed the reference group. They were submitted to the same medical procedure, laboratory investigations, and circulatory function test as the exposed workers.

\section{COLD PROYOCATION TEST}

To assess peripheral vascular function, a cold test was performed on the right hand of the referents and the exposed workers. Skin temperature was measured on the dorsal surface of midphalanx of the third right finger before and after immersion of the hand in cold water $\left(4^{\circ} \mathrm{C}\right)$ for two minutes. A thermistor probe (LSI, Milan, Italy) was used for skin thermometry. The rewarming time of the finger was evaluated by monitoring skin temperature every three minutes during the first 30 minutes after the cooling period. The cold test was carried out at room temperature of $22.5^{\circ} \mathrm{C}\left(\mathrm{SD} 0.4^{\circ} \mathrm{C}\right)$.

\section{LABORATORY DATA}

Platelet function and clotting parameters were studied in all 113 subjects. Venous blood collection was performed in the early morning using a nonocclusive technique. Venous samples were withdrawn after an overnight fast, after 12 hours of smoking abstinence, and after abstention from anti- platelet drugs for at least 10 days.

PLATELET AGGREGATION

Platelet aggregation was performed according to Born's photometric method. ${ }^{12}$ The blood sample (18 $\mathrm{ml}$ ) was withdrawn into a plastic syringe containing $2.0 \mathrm{ml}$ of $3.8 \%$ sodium citrate. Platelet rich plasma was prepared by centrifuging the citrated blood into plastic tubes at $400 \mathrm{rpm}$ and counted by an automatic platelet counter (ULTRA FLO 100). Platelet aggregation was determined by a photometer ELVI 840 assuming the transmittance of platelet poor plasma as $100 \%$ of aggregation. The sample, adjusted to contain $300-350000$ platelet $/ \mathrm{mm}^{3}$, was tested with adrenaline at $4.0 \mu \mathrm{M}$ and with ADP at $0.8 \mu \mathrm{M}$. The transmittance value $(\%)$ after five minutes of platelet aggregation was assumed. The ADP threshold concentration inducing the release reaction was also determined.

\section{BETA-THROMBOGLOBULIN}

The blood was collected using evacuated glass tubes (Abbott) ${ }^{13}$ containing $2.5 \%$ ethylenediaminetetraacetate, $0.025 \%$ chloradenosine, and $7 \%$ procaine-hydrochloric acid. Beta-thromboglobulin levels were assayed using the Amersham Ria Kit according to Ludlam et al. ${ }^{14}$

\section{PLATELET FACTOR FOUR}

Platelet factor four levels were assayed with the use of the Abbott Ria Kit. The collection and preparation of the samples were the same as previously described for beta-thromboglobulin.

\section{PLATELET FACTOR THREE}

This was considered as Stypven time ${ }^{15}$ and performed on platelet rich plasma by a semiautomatic instrument (Fibrintimer Labor).

\section{FIBRINOPEPTIDE A}

Fibrinopeptide A was assayed using the Mallinckrodt Kit according to Nossel et al..$^{16}$

\section{ANTITHROMBIN III}

Antithrombin III was determined by chromogenic substrate (Abbott Kit). ${ }^{17}$

Platelet count, fibrinogen, total and high density lipoprotein cholesterol, triglycerides, and immunoglobulins $G, A$, and $M$ were also determined in the exposed and reference workers.

\section{VIBRATION MEASUREMENT AND VIBRATION DOSE}

Vibration measurements were made at the work site, and two skilled operators were requested to use the vibrating tools under normal working condi- 
tions. Vibrating handheld tools consisted of a pneumatic chipping hammer and a straight grinder. A delta shear type accelerometer (B\& K 4367) and a shock accelerometer (B\&K 8309) were rigidly fastened to the handles of the grinder and chipping hammer. The signal from the transducers was fed into charge amplifiers (B\&K 2635) and recorded on a FM tape recorder (B\&K 7003). Vibrations were measured in the three axes $\mathrm{X}, \mathrm{Y}, \mathrm{Z}$ with a frequency range from $0.2 \mathrm{~Hz}$ to $3000 \mathrm{~Hz}$. One third octave band frequency spectra of the recorded vibration signals were obtained in the laboratory using a digital frequency analyser (B\&K 2131) connected to a graphics recorder $(B \& K$ 2313). The magnitude of the vibration at each $1 / 3$ octave centre frequency from $6.3 \mathrm{~Hz}$ to $1250 \mathrm{~Hz}$ was calculated as acceleration level in decibels:

$$
\mathrm{L}_{\mathrm{h}}=20 \log \left(\mathrm{a} / \mathrm{a}_{\mathrm{o}}\right)
$$

where $\mathrm{a}=\mathrm{rms}$ acceleration in $\mathrm{m} / \mathrm{s}^{2}$ and $\mathrm{a}_{\mathrm{o}}=$ reference acceleration of $10^{-6} \mathrm{~m} / \mathrm{s}^{2}$.

From the results of the frequency analysis, the weighted acceleration level $\left(\mathrm{L}_{\mathrm{hw}}\right)$ of vibration was computed using the frequency weighting factors and the equation proposed by ISO/DIS 5349. ${ }^{18}$

Table 1 gives the weighted acceleration levels measured in three orthogonal axes of the vibrating tools.

According to the method specified in ISO/DIS $5349,{ }^{18}$ the daily exposure to vibration for each foundry worker was characterised in terms of four hour energy-equivalent frequency weighted acceleration level, $\left(\mathrm{L}_{\mathrm{hw}}\right)_{\mathrm{eq}}^{\mathrm{t}=4}$, by the formula:

$$
\left(L_{h w}\right)_{e q}^{t=4}=\left(L_{h w}\right)_{e q}^{t=t}+10 \log (t / 4)
$$

where $\left(L_{h w}\right)_{e q}^{t=t}$ is the equivalent frequency weighted acceleration level for a daily exposure of $t$ hours.

On the basis of duration of exposure to vibration (years), a vibration exposure level (VEL) was also computed for each operator. This index represents the total energy level entering the fingers and the hands of the workers exposed to vibration over a specified period. The vibration exposure level was calculated as follows:

$$
\operatorname{VEL}=\left(\mathrm{L}_{\mathrm{hw}}\right)_{\mathrm{eq}}^{\mathrm{t}=4}+10 \log \left(\mathrm{T} / \mathrm{T}_{\mathrm{o}}\right)
$$

where $T$ is the total exposure time in years and $T_{0}$ a reference year that comprises 240 days of vibration exposure.

\section{STATISTICAL METHODS}

Student's $t$ test, chi square test, and bivariate correlation and linear regression analyses were used for statistical evaluation of the data. A probability level of 0.05 was stated as the limit of statistical significance.

\section{Results}

\section{PREVALENCE OF SYMPTOMS AND VIBRATION} EXPOSURE

The information derived from the questionnaire and the medical interview were used for staging the neurological and vascular symptoms according to Taylor's classification. Of the 67 workers exposed to vibration, nine $(13.4 \%)$ had no disturbances (stage $0)$ and $44(65.6 \%)$ complained of neurological symptoms; among these latter, $31(46 \cdot 2 \%)$ were affected by tingling (stage $0_{\mathrm{T}}$ ) and $13(19.4 \%)$ by numbness (stage $0_{\mathrm{N}}$ ) in the fingers. The remaining 14 foundry workers $(20.9 \%)$ suffered from Raynaud's phenomenon of occupational origin: nine workers were in stage $1(13.4 \%)$, four in stage 2 $(5.9 \%)$, and one in stage $3(1.5 \%)$. Among the workers with white fingers, the right hand was more affected $(85.7 \%)$ than the left $(57.1 \%)$; six men $(42 \cdot 8 \%)$ reported vasospastic attacks in both hands. The highest prevalence of blanching symptoms occurred in the third right $(57 \cdot 1 \%)$ and left $(42.8 \%)$ fingers. Neurological disturbances were present in all the workers with vasospastic syndrome. None of the 46 referents was found to be suffering from Raynaud's phenomenon or disease and only two men complained of paresthaesia in the fingers.

Table 2 gives the age, exposure time, and vibration exposure level of the foundry workers. Foundry workers affected with Raynaud's phenomenon were older than the other exposed workers. Exposure to vibration expressed both as working time (years and total hours) and as vibration exposure level (dB) was significantly higher in the workers with vascular symptoms than in those with no symptoms or with

Table 1 Weighted acceleration levels $\left(L_{h w}\right.$ in $\left.d B\right)$ measured at the handle of vibrating tools in three orthogonal axes $X, Y, Z$

\begin{tabular}{lllll}
\hline Tools & \multicolumn{2}{l}{$\begin{array}{l}\text { Centre frequency } \\
(H z)\end{array}$} & \multicolumn{3}{l}{ Weighted acceleration level $\left(d B^{*}\right)$} \\
\cline { 3 - 5 } & & $L_{h w}(x)$ & $L_{h w}(y)$ & $L_{h w}(z)$ \\
\hline Chipping hammer & $31 \cdot 5$ & 149 & 146 & 150 \\
Straight grinder & 125 & 139 & 137 & 138 \\
\hline
\end{tabular}

${ }^{*} \mathrm{~dB}$ re $10^{-6} \mathrm{~m} / \mathrm{s}^{2}$. 
Table 2 Age, exposure time, and vibration dose in the vibration exposed workers. Values are given as mean (SD)

\begin{tabular}{|c|c|c|c|c|}
\hline \multirow[t]{2}{*}{ Characteristics } & \multicolumn{4}{|c|}{ Stages of vibration induced white finger } \\
\hline & $\begin{array}{l}\text { Stage 0 } \\
(n=9)\end{array}$ & $\begin{array}{l}\text { Stages } 0_{T}-0_{N} \\
(n=44)\end{array}$ & $\begin{array}{l}\text { Stages 1-2-3 } \\
(n=14)\end{array}$ & $\begin{array}{l}\text { Total } \\
(n=67)\end{array}$ \\
\hline $\begin{array}{l}\text { Age (years) } \\
\text { Duration of exposure (years) } \\
\text { Total working time (hours) } \\
\text { Vibration exposure level (dB) }\end{array}$ & $\begin{array}{r}38 \cdot 8(7 \cdot 3) \\
5 \cdot 6(4 \cdot 5) \\
2056(1405) \\
144(6 \cdot 5)\end{array}$ & $\begin{array}{r}38 \cdot 5(7 \cdot 6) \\
9 \cdot 1(5 \cdot 8) \\
3629(2423) \\
151(5 \cdot 1)^{* *}\end{array}$ & $\begin{array}{r}43.7(5.4)^{\star} \\
16.5(6.0)^{* \circ} \\
10978(5604)^{* \circ} \\
157(3.3)^{* 0}\end{array}$ & $\begin{array}{r}39 \cdot 6(7 \cdot 3) \\
10 \cdot 2(6 \cdot 6) \\
4953(4501) \\
151(6 \cdot 1)\end{array}$ \\
\hline
\end{tabular}

Significant from stage $0:{ }^{*} \mathrm{p}<0.001 ;{ }^{* *} \mathrm{p}<0.01$.

Significant from stages $0_{\mathrm{T}}-0_{\mathrm{N}}:^{\circ} \mathrm{p}<0.005 ;{ }^{\wedge} \mathrm{p}<0.025$.

neurological complaints alone. The relation between vibration exposure level and severity of the staging symptoms of VWF is evident from table 3 . The mean and median latencies of blanching for workers with stages $1-2-3$ were 9.2 years (SD 6.8) and 8.0 years (range $2-25$ ) respectively. The latent period is here considered as exposure time before the onset of finger blanching.

\section{PLATELET FUNCTION AND COAGULATION PARAMETERS}

In table 4 the main characteristics of the workers exposed to vibration are compared with those of the referents. No difference was found between the referent group and the entire exposed population.
Nevertheless, when the vibration workers were subdivided into different stages of VWF, subjects with blanching symptoms showed a significantly higher diastolic blood pressure and total cholesterol level than the referents and the other exposed workers. The diastolic arterial pressure and total cholesterol levels correlated well with the age of all subjects $(r$ $=0.38, \mathrm{p}<0.001)$.

Table 5 shows the results of the platelet functions tests and the clotting assays. Indices of platelet aggregation both in vitro and in vivo, antithrombin III, fibrinogen, and fibrinopeptide $A$ levels did not differ significantly in the exposed workers at different stages of VWF compared with the referents. No relation was found between the haemostatic para-

Table 3 Vibration exposure level and severity of symptoms in the fingers of foundry workers using chipping and grinding tools. Values are given as numbers (\%)

\begin{tabular}{llcl}
\hline $\begin{array}{l}\text { Stages of } \\
\text { vibration white finger }\end{array}$ & \multicolumn{4}{l}{ Vibration exposure level } & \\
\cline { 2 - 4 } & $\leqslant 145 d B$ & $146-155 d B$ & $\geqslant 156 d B$ \\
\hline $\begin{array}{l}\text { Stage } 0(\mathrm{n}=9) \\
\text { Stages } 0 \mathrm{~T}-0 \mathrm{~N}(\mathrm{n}=44)\end{array}$ & $6(8 \cdot 9)$ & $3(4 \cdot 5)$ & $\overline{10}(14 \cdot 9)$ \\
Stages $1-2-3(\mathrm{n}=14)$ & $-5 \cdot 5)$ & $29(43 \cdot 2)$ & $12(17 \cdot 9)$ \\
Total $(\mathrm{n}=67)$ & $11(16 \cdot 4)$ & $34(50 \cdot 7)$ & $22(32 \cdot 8)$ \\
\hline
\end{tabular}

Chi square value: $39 \cdot 2(p<0 \cdot 0005)$.

Table 4 Age, anthropometric data, smoking and alcohol habits, blood pressure, and serum lipid concentrations in referents and vibration exposed workers. Values are given as mean (SD)

\begin{tabular}{|c|c|c|c|c|c|}
\hline & \multirow{2}{*}{$\begin{array}{l}\text { Referents } \\
(n=46)\end{array}$} & \multicolumn{4}{|c|}{ Chipping and grinding operators } \\
\hline & & $\begin{array}{l}\text { Stage 0 } \\
(n=9)\end{array}$ & $\underset{(n=44)}{\text { Stages } 0} T^{-0} N$ & $\begin{array}{l}\text { Stages 1-2-3 } \\
(n=14)\end{array}$ & $\begin{array}{l}\text { Total } \\
(n=67)\end{array}$ \\
\hline $\begin{array}{l}\text { Age (years) } \\
\text { Body surface area }\left(\mathrm{m}^{2}\right) \\
\text { Cigarette consumption (total packets) } \\
\text { Alcohol }(\mathrm{g} / \mathrm{d}) \\
\text { Systolic arterial pressure (mm } \mathrm{Hg}) \\
\text { Diastolic arterial pressure (mm } \mathrm{Hg}) \\
\text { Total cholesterol (mg/dl) }\end{array}$ & $\begin{array}{l}39 \cdot 6(7 \cdot 2) \\
1 \cdot 96(0 \cdot 15) \\
4785(4.543) \\
40 \cdot 6(26 \cdot 4) \\
130(12 \cdot 8) \\
82 \cdot 5(10 \cdot 2) \\
228(48 \cdot 9)\end{array}$ & $\begin{array}{c}38 \cdot 8(7 \cdot 3) \\
1 \cdot 93(0 \cdot 09) \\
4156(4,232) \\
43 \cdot 3(29 \cdot 2) \\
127(7 \cdot 9) \\
81 \cdot 1(6 \cdot 5) \\
202(32 \cdot 1)\end{array}$ & $\begin{array}{c}38 \cdot 5(7 \cdot 6) \\
1 \cdot 93(0 \cdot 14) \\
3888(4,056) \\
48 \cdot 9(33 \cdot 3) \\
127(12 \cdot 8) \\
84 \cdot 3(9 \cdot 7) \\
223(53 \cdot 3)\end{array}$ & $\begin{array}{c}43 \cdot 7(5 \cdot 4)^{* *} \\
1 \cdot 93(0 \cdot 09) \\
2495(3,454) \\
35 \cdot 2(14 \cdot 9) \\
135(16 \cdot 9) \\
88 \cdot 9(8 \cdot 5)^{*} \\
265(52 \cdot 8)^{* *}\end{array}$ & $\begin{array}{l}39 \cdot 6(7 \cdot 3) \\
1 \cdot 93(0 \cdot 12) \\
3633(3,949) \\
45 \cdot 3(30 \cdot 1) \\
129(13 \cdot 4) \\
84 \cdot 8(9 \cdot 3) \\
229(54 \cdot 1)\end{array}$ \\
\hline $\begin{array}{l}\text { High density lipoprotein } \\
\text { cholesterol (mg/dl) } \\
\text { Triglycerides }(\mathrm{mg} / \mathrm{dl})\end{array}$ & $\begin{array}{c}54 \cdot 2(19 \cdot 8) \\
141(95 \cdot 1)\end{array}$ & $\begin{array}{c}48 \cdot 6(19 \cdot 7) \\
118(61 \cdot 0)\end{array}$ & $\begin{array}{r}50 \cdot 2(9 \cdot 1) \\
114(58 \cdot 1)\end{array}$ & $\begin{array}{l}55 \cdot 7(10 \cdot 1) \\
110(54 \cdot 1)\end{array}$ & $\begin{array}{l}50.6(11 \cdot 1) \\
114(56 \cdot 8)\end{array}$ \\
\hline
\end{tabular}

Significant from referents: ${ }^{*} p<0.05 ;{ }^{* *} p<0.025$. 
Table 5 Platelet count, in vitro and in vivo platelet aggregation indices, and blood coagulation parameters in referent and vibration exposed groups. Values are given as mean (SD)

\begin{tabular}{|c|c|c|c|c|c|}
\hline & \multirow{2}{*}{$\begin{array}{l}\text { Referents } \\
(n=46)\end{array}$} & \multicolumn{4}{|c|}{ Chipping and grinding operators } \\
\hline & & $\begin{array}{l}\text { Stage } 0 \\
(n=9)\end{array}$ & $\begin{array}{l}\text { Stages } 0_{T}-0_{N} \\
(n=44)\end{array}$ & $\begin{array}{l}\text { Stages } 1-2-3 \\
(n=14)\end{array}$ & $\begin{array}{l}\text { Total } \\
(n=67)\end{array}$ \\
\hline $\begin{array}{l}\text { Platelet count }\left(\times 10^{3} / \mathrm{mm}^{3}\right) \\
\mathrm{A}_{\text {s }} \text { adenosine-diphosphate }(\%) \\
\mathrm{A}_{5} \text { epinephrine }(\%) \\
\text { Adenosine-diphosphate } \\
\text { (threshold) }\left(\times 10^{-6} \mathrm{M}\right)\end{array}$ & $\begin{array}{l}235(52 \cdot 1) \\
42 \cdot 3(25 \cdot 9) \\
45 \cdot 1(20 \cdot 9) \\
0.79(0 \cdot 90)\end{array}$ & $\begin{array}{r}213(38 \cdot 5) \\
52 \cdot 2(18 \cdot 2) \\
47 \cdot 2(10 \cdot 8) \\
0.74(1 \cdot 11)\end{array}$ & $\begin{array}{l}238(62.2) \\
55.4(66.6) \\
40.5(22.5) \\
0.99(1.01)\end{array}$ & $\begin{array}{r}231(77 \cdot 9) \\
45 \cdot 0(34 \cdot 0) \\
42 \cdot 2(29 \cdot 4) \\
1 \cdot 02(0 \cdot 60)\end{array}$ & $\begin{array}{r}233(60.6) \\
50.3(57 \cdot 2) \\
42.0(21 \cdot 5) \\
0.97(0.97)\end{array}$ \\
\hline $\begin{array}{l}\text { Platelet factor three/platelet } \\
\text { rich plasma (s) } \\
\text { Platelet factor four (ng/dl) } \\
\text { Beta-thromboglobulin (ng/dl) } \\
\text { Antithrombin III (\%) } \\
\text { Fibrinogen (mg/dl) } \\
\text { Fibrinopeptide A (ng/ml) }\end{array}$ & $\begin{array}{c}46 \cdot 7(11 \cdot 1) \\
15 \cdot 8(14 \cdot 0) \\
55 \cdot 1(31 \cdot 0) \\
100(14 \cdot 2) \\
244(88 \cdot 4) \\
5.4(3 \cdot 3)\end{array}$ & $\begin{array}{r}53.0(9.1) \\
12.3(3 \cdot 6) \\
36.7(6 \cdot 9) \\
106(19 \cdot 9) \\
260(41 \cdot 9) \\
5.8(3 \cdot 1)\end{array}$ & $\begin{array}{c}50 \cdot 8(7 \cdot 5) \\
11 \cdot 6(9 \cdot 2) \\
42 \cdot 6(25 \cdot 6) \\
107(17 \cdot 6) \\
235(46 \cdot 1) \\
6.6(3 \cdot 3)\end{array}$ & $\begin{array}{r}48.9(13.0) \\
16 \cdot 5(19 \cdot 7) \\
56 \cdot 4(36.6) \\
101(17.8) \\
245(27.6) \\
5.7(3.8)\end{array}$ & $\begin{array}{c}51 \cdot 0(8 \cdot 4) \\
14 \cdot 2(10 \cdot 35) \\
47.7(25 \cdot 5) \\
106(17 \cdot 6) \\
241(43 \cdot 3) \\
6 \cdot 2(3.5)\end{array}$ \\
\hline
\end{tabular}

meters and the stages of vibration syndrome or between the haemostatic parameters and the duration of exposure to vibration.

\section{PERIPHERAL CIRCULATORY FUNCTION}

Figure 1 displays the results of the cold provocation test performed on the right hand of the referent and exposed groups. At rest, the mean skin digital temperature was lower in the workers affected by white finger than in the referents $(p=0.016)$. Local cooling induced blanching of the fingers in six of the 14 subjects $(42.8 \%)$ suffering from Raynaud's

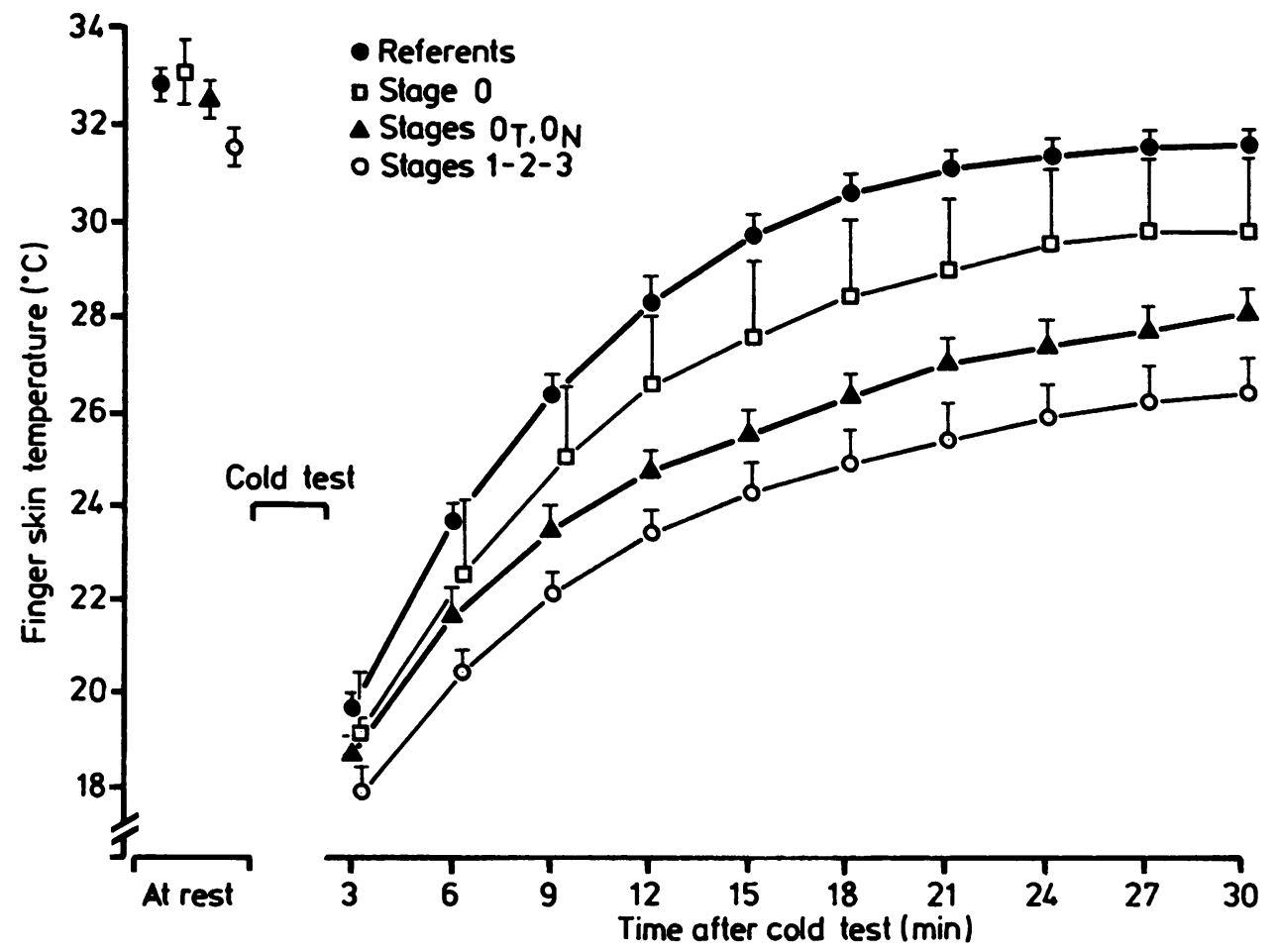

Fig 1 Digital skin temperature curves during furst 30 minutes after cold test in referents and workers exposed to vibration subdivided into different stages of VWF. Plotted values represent means and standard errors of means. Significant from referents: $\left(\right.$ (A) Stages $0_{T}-0_{N}: 3 \min p=0.019,6-30$ min $p<0.001$. (B) Stages 1-2-3: at rest $p=0.016,3 \min p<0.005,6-30 \min p<0.001$. 


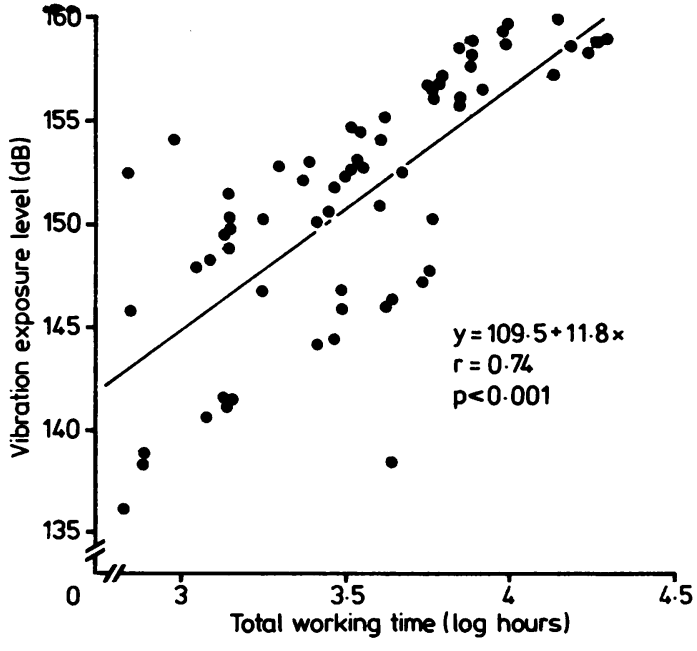

Fig 2 Correlation between vibration exposure level and total working time in workers exposed to vibration.

phenomenon. The monitoring of skin temperature of the third right finger after cold stimulation showed that the rewarming rate was significantly slower in the exposed workers with neurological (stages $0_{\mathrm{T}}, 0_{\mathrm{N}}$ ) and vascular (stages 1-2-3) symptoms than in the referents $(p=0.019-0.0001)$. The temperature curves indicate that the more severe the vibration syndrome, the lower the digital skin temperature at each time of the rewarming period, even if the differences were not significant.

\section{Discussion}

In the present study the severity of neurological and vascular symptoms of chipping and grinding operators showed a strong dependence on occupational exposure to vibration. There was evidence for a significant relationship between the stages of VWF and the vibration dose. No foundry worker affected with Raynaud's phenomenon had worked with vibrating tools for less than $\mathbf{3 5 0 0}$ hours nor had he been exposed to a cumulative weighted acceleration level of less than $148 \mathrm{~dB}$. Total working hours and vibra- tion exposure levels were good indices of vibration dose and correlated well (fig 2). These findings agree with those of other studies which have reported a direct association between exposure time and the severity of vibration syndrome. ${ }^{11920}$

The laboratory investigations showed that no anomalous changes in haemostatic function could be shown in the chipping and grinding workers when compared with the referents. Neither in vitro platelet aggregation induced by adenosinediphosphate and adrenaline nor specific markers of in vivo platelet release reaction (betathromboglobulin and platelet factor four) were found to differ among the referents or exposed workers subdivided into various stages of VWF. Assays of other important parameters of blood coagulation such as antithrombin III and fibrinopeptide $A$ indicated that in vivo clotting control and thrombin activity were also normal in both groups.

Platelet disorders have been reported in patients suffering from Raynaud's phenomenon not due to the use of vibrating tools. ${ }^{13}$ Endothelial damage is considered to be the primary event for in vivo platelet activation and for the development of thrombotic processes. In patients affected with collagen disease a vasospastic syndrome and platelet abnormalities are often associated with immunological alterations such as an increase in serum immunoglobulins. $^{2122}$ The normality of our haemostatic and immunological data (tables 5 and 6 ) indicate that in the exposed workers mechanical vibration neither provokes injury to the endothelial layer of arterial wall nor induces changes in humoral immunity.

As finger skin temperature is related to total digital blood flow, ${ }^{2324}$ curve patterns of temperature recovery time after the cold test indicate that in exposed workers digital arteries responded to local cooling with a more pronounced vasoconstriction than in the referents. Among the chipping and grinding operators, moreover, the release of arterial vasospasm after the cooling procedure was slower in those subjects suffering from Raynaud's phenomenon than in those with no symptoms or with neurological disturbances alone. Studying the effects of vibratory stimulation on the femoral arteries of

Table 6 Concentration of serum immunoglobulins (Ig) in referents and vibration exposed workers. Values are given as mean (SD)

\begin{tabular}{|c|c|c|c|c|c|}
\hline & \multirow{2}{*}{$\begin{array}{l}\text { Referents } \\
(n=46)\end{array}$} & \multicolumn{4}{|c|}{ Chipping and grinding operators } \\
\hline & & $\begin{array}{l}\text { Stage 0 } \\
(n=9)\end{array}$ & $\begin{array}{l}\text { Stages } 0_{T}-O_{N} \\
(n=44)\end{array}$ & $\begin{array}{l}\text { Stages 1-2-3 } \\
(n=14)\end{array}$ & $\begin{array}{l}\text { Total } \\
(n=67)\end{array}$ \\
\hline $\begin{array}{l}\operatorname{IgG}(\mathrm{mg} / \mathrm{dl}) \\
\operatorname{IgA}(\mathrm{mg} / \mathrm{dl}) \\
\text { IgM (mg/dl) }\end{array}$ & $\begin{array}{c}1166(210) \\
242(91) \\
124(51)\end{array}$ & $\begin{array}{r}1193(352) \\
252(82) \\
118(93)\end{array}$ & $\begin{array}{c}1170(155) \\
256(96) \\
146(69)\end{array}$ & $\begin{array}{r}1164(168) \\
254 \\
155(69) \\
(54)\end{array}$ & 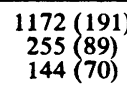 \\
\hline
\end{tabular}


dogs and rats, Azuma et al have shown that vibration induced hyperresponsiveness of the arterial smooth muscles to noradrenaline. ${ }^{25}$ These experiments support the opinion that hyperreactivity of the digital vessel observed in workers exposed to vibration may be due to a local vibratory stress that enhances the responsiveness of the arterial muscular wall to sympathetic stimuli such as loud noise or cold. 2627

The findings of the present study extend our previous suggestions" - that is, that not only in the early stages $\left(0_{\mathrm{T}}, 0_{\mathrm{N}}\right)$ but also in the more severe stages of VWF (stages 1-2) both cold induced hyperreactivity in the digital vessels and Raynaud's syndrome are vascular disorders of functional origin occurring with no prethrombotic alterations.

\section{References}

' Zahavi J, Kakkar VV. Beta-thromboglobulin-a specific marker of in-vivo platelet release reaction. Thromb Haemostas 1980;44:23-9.

2 Zahavi J, Hamilton WAP, O' Reilly MJG, Clark SE, Cotton LT, Kakkar VV. Abnormal platelet function in Raynaud's phenomenon. Thromb Haemostas 1979;42:146.

${ }^{3}$ Blunt RJ, George AJ, Hurlow RA, Strachan CJL, Stuart J. Hyperviscosity and thrombotic changes in idiopathic and secondary Raynaud's syndrome. Br J Haematol 1980;45:651-8.

4 O' Reilly MJG, Zahavi J, Dubiel M, Cotton LT, Kakkar VV. Plasmapheresis and platelet function in Raynaud's phenomenon. Thromb Haemostas 1979; 42:338.

${ }^{5}$ Nerem RM. Vibration-induced arterial shear stress: the relationship to Raynaud's phenomenon of occupational origin. Arch Environ Health 1973;26:105-10.

- Zedda S, Marracini L, Sergiacomi R. Sul comportamento dell' emocoagulazione negli operai addetti all' uso di strumenti vibranti. Rassegna Medica Sarda 1968;71:608-18.

' Sroczynski J, Wegiel A, Pigon W. Blood coagulation system in workers exposed to noise and vibration. Medycyna Pracy 1979;30:41-7.

${ }^{8}$ Ikehata K, Kawauchi S, Kohno F. Increased platelet function and von Willebrand factor in vibration syndrome. Tokushima $J$ Exp Med 1980;27:23-8.

${ }^{4}$ Bovenzi M, Fiorito A, Giansante C, Calabrese S, Negro C. Platelet function and clotting parameters of vibration-exposed foundry workers. Scand J Work Environ Health 1983;9:34752.

${ }^{10}$ Taylor W, Pelmear PL, Pearson J. Raynaud's phenomenon in forestry chain saw operators. In: Taylor $\mathrm{W}$, ed. The vibration syndrome. London: Academic Press, 1974:121-39.
"Miyashita K, Shiomi S, Itoh N, Kasamatsu T, Iwata $H$. Epidemiological study of vibration syndrome in response to total hand-tool operating time. Br J Ind Med 1983;40:92-8.

12 Born GVR. Aggregation of blood platelets by adenosinediphosphate and its reversal. Nature 1962;194:927-9.

${ }^{13}$ Eche N, Bonev A, Sie P, Lucot H. Evacuated blood collection tubes and the determination of betathromboglobulin. Thromb Res 1981;3:323-4.

14 Ludlam CA, Moore S, Bolton AE, Pepper DS, Cash JD. The release of a human platelet specific protein measured by RIA. Thromb Res 1975;6:543-8.

is Spaet TH, Cintron J. Studies on PF3 availability. Br J Haematol 1965;11:269-75.

${ }^{16}$ Nossel HL, Yudehman I, Calfield RE. Measurement of fibrinopeptide $A$ in human blood. J Clin Invest 1974;54:43-53.

17 Øegard OR, Lie M, Abilgaard U. Heparin cofactor activity measured with amidolytic method. Thromb Res 1975;6:28794.

${ }^{18}$ International Organization for Standardization. Guide for the measurement and the evaluation of human exposure to vibration transmitted to the hand. Berlin: Deutsches Institut Für Normung, 1983. (Second draft international standard ISO/ DIS 5349.)

${ }^{14}$ Brubaker RL, Mackenzie CJG, Eng PR, Bates DV. Vibration white finger disease among tree fellers in British Columbia. $J$ Occup Med 1983;25:403-8.

${ }^{20}$ Wasserman DE, Taylor W, Behrens V, Samueloff S, Reynolds D. Vibration white finger disease in US workers using pneumatic chipping and grinding handtools. I: Epidemiological results. Cincinnati: US Department of Health and Human Services, Public Health Service, Centers for Disease Control, National Institute for Occupational Safety and Health, 1982. (DHHS (NIOSH) publication No 82-118.)

2: Porter JM, Snider RL, Bardana EJ, Rösch J, Eidemiller LR. The diagnosis and treatment of Raynaud's phenomenon. Surgery 1975; 77:11-23.

22 Porter JM, Bardana EJ, Baur GM, Wesche DH, Andrasch RH, Rösch J. The clinical significance of Raynaud's syndrome. Surgery 1976;80:756-64.

${ }^{23}$ Burton AC. Temperature of skin: measurement and use as index of peripheral blood flow, In: Methods in medical research. Chicago: Year Book, 1948:146-66.

${ }^{24}$ Felder F, Russ E, Montgomery H, Horwitz O. Relationship in the toe of skin surface temperature to mean blood flow measured with a plethysmograph. Clin Sci 1954;13:251-7.

${ }^{25}$ Azuma T, Ohhashi T, Sakaguchi M. Vibration-induced hyperresponsiveness of arterial smooth muscle to noradrenaline with special reference to Raynaud's phenomenon in vibration disease. Cardiovasc Res 1978; 12:758-64.

${ }^{26}$ Pyykkö I. A physiological study of the vasoconstrictor reflex in traumatic vasospastic disease. Work Environ Health 1974;11:170-86.

${ }^{27}$ Matoba T, Kusumoto H, Omura H, Kotorii T, Kuwahara H, Takamatsu M. Digital plethysmographic responses to auditory stimuli in patients with vibration disease. Tohoku J Exp Med 1975; 115:385-92. 